БЕЗОПАСНОСТЬ ЦИФРОВЫХ ТЕХНОЛОГИЙ. - 2021. - № 4 (103). - 9-19

\author{
АВТОМАТИЗАЦИЯ И УПРАВЛЕНИЕ \\ ТЕХНОЛОГИЧЕСКИМИ ПРОЦЕССАМИ \\ И ПРОИЗВОДСТВАМИ
}

УДК 004.616-71

DOI: $10.17212 / 2782-2230-2021-4-9-19$

\title{
MODELING OF A HARDWARE AND SOFTWARE COMPLEX "POLIGRAF" BASED ON FREELY DISTRIBUTABLE MICROCONTROLLER PLATFORMS*
}

\author{
VIKTOR A. MASHTAKOV ${ }^{1}$, VIKTOR M. BELOV ${ }^{2}$ \\ ${ }^{1} 20$ Karl Marx Avenue, Novosibirsk, 1630073, Russian Federation, Novosibirsk State Tech- \\ nical University, master's student of the Department of Information Security. E-mail: \\ vitya.mashtakov@gmail.com \\ ${ }^{2} 20$ Karl Marx Avenue, Novosibirsk, 630073, Russian Federation, Novosibirsk State Tech- \\ nical University, doctor of technical sciences, professor of the Department of Information Se- \\ curity.E-mail:vmbelov@mail.ru
}

This article is devoted to the modeling of the software and hardware complex (SHC) "Polygraph" on the basis of freely distributed microcontroller platforms. In the work, the analysis of primary sources was carried out and the most promising microcontroller platform for the purposes of visual modeling and training to work on such devices was chosen. Within the framework of modeling tasks, on the basis of a number of criteria, the most optimal automated system for the design of devices has been determined. Using the chosen toolkit, the authors modeled the first educational test version of "Polygraph" with the ability to display some parameters measured by real SHC. The article considered the connection of the following sensors of the SHC "Polygraph": pulse, body temperature and respiratory rate. Based on the work done, it was concluded that this development is promising and relevant for design purposes and training in work on devices such as "Polygraph".

Keywords: component, polygraph, microcontroller platform, sensor, software and hardware complex, computer-aided design system, photoplethysmography, model

\section{INTRODUCTION}

Currently, law enforcement agencies, government agencies, as well as some commercial enterprises use a device called "Polygraph" when hiring. It is used to select applicants for vacancies, investigate various kinds of offenses, etc. Let's try to give the most general definition of this technical device. "Polygraph", in our opin-

\footnotetext{
${ }^{*}$ Received 10 November 2021.
} 
ion, is a technical device designed for simultaneous simultaneous measurement of psychophysiological characteristics of a person (respiration indicators, skin conductivity, heart rate, etc.) and presentation of measurement results in digital or analog form to determine the reliability of information received from of the interrogated person $[1,2]$. Today, in the era of universal digitalization of world socio-economic relations, everyone who wants to use a polygraph faces several serious problems: the high cost of the device and the high cost of its maintenance. This article discusses the possibility of modeling SHC "Polygraph" on the basis of freely distributed microcontroller platforms: analysis of primary sources is carried out in order to select the most optimal microcontroller platform (MP) and computer-aided design (CAD) system according to certain criteria; the simulation results are shown after connecting a number of sensors.

\section{THEORY}

\section{A. Task Statement}

To The task is to simulate a model of SHC "Poligraf" in one of CADs, with subsequent presentation of the design results in the form of a structural model, with a description of the principle of the device.

\section{B. Selection of Microcontroller Platform}

At the moment, the most widely known and popular among the developers and ordinary users are two platforms: Arduino and Raspberry Pie. The platforms are recognized for their simplicity and ease of use, as well as rather simple to learn basic functions, even if the user is using any of them for the first time. In order to understand which platform is better to use, it is necessary to conduct a comparative analysis. The analysis was based on the following criteria: ease of use and interaction with the platform; complexity of programming language and development tools; platform flexibility and the ability to adapt to different projects; demand for power supply systems; system crash tolerance [2].

- The Raspberry $\mathrm{Pi}$ is a computer that can run a Linux operating system that supports multitasking. Various devices can be connected to the USB ports, e.g. for wireless connection to the Internet. The platform is very powerful and can function as a complete personal computer (PC) [3].

- The Arduino can read analog signals in real time better than the Raspberry Pi. Arduino's versatility allows it to operate with practically any type of chips and sensors. The Raspberry $\mathrm{Pi}$ is much more selective with analog sensors: additional hardware is required.

- Arduino is less demanding on the power system of the devices. The recommended power supply for Arduino UNO is $7-12 \mathrm{~V}$, which can be stabilized to $5 \mathrm{~V}$. 
The Raspberry Pi platform requires strictly $5 \mathrm{~V}$ input, so it requires a power filter with 1 A current [4].

- Arduino's development environment is much easier to use than Linux for instance, to be able to create a program for a flashing LED on the Raspberry Pi, it requires an operation system (OS) and certain program code libraries. On the other hand with the Arduino, it is possible to write a similar program using only eight lines of program code. Because the Arduino is not meant to run many applications or the OS, it is possible to simply plug in the platform and start working.

- The Arduino can work with any power supply and PC. The Arduino can be switched on/off at will during operation, which makes it different from the Raspberry $\mathrm{Pi}$, whose OS can be damaged if the board is switched off without a proper shutdown session.

Based on all the above mentioned advantages and disadvantages of the discussed platforms, it follows that Arduino has an undeniable advantage in the realization of hardware-software projects, including the solution of our task [5].

\section{CADs Selection}

Once the microcontroller platform has been defined, it is necessary to choose the software for further design of the device. The choice of a suitable system was made on the basis of the following factors: the breadth of software functionality; the ability to perform all stages of development; the possibility of connecting thirdparty libraries; the ability to simulate the external impact on the designed device.

Among different software, the most promising for solving the problem is the Proteus software. The main advantages and features of Proteus functionality are as follows:

- the widest functionality for working with microcontroller platforms in comparison with all existing analogs;

- proteus contains over than 6000 electronic elements with full reference data and also demonstration projects;

- USBCONN and COMPIM tools that allow to connecting virtual device to the USB and COM ports of computer;

- the possibility to perform all the stages of development of an electronic device based on a microcontroller in a single environment;

- possibility to write, debug and test the firmware even before the prototype is physically built;

- a preinstalled set of models of most electronic components sorted by type;

- a wide selection of third-party component libraries that are created by enthusiasts around the world and are freely available;

- an electronic circuit simulator that can be used to see how a device behaves in operation; 
- simulators of sensors and tools of external influence: it is possible to change the sensor readings, watching how the system reacts to it;

- applying the available Proteus features and capabilities, it is possible to not only fully meet the needs of the project, but also to obtain the necessary opportunities for experimentation and complete debugging of the device under development, avoiding unnecessary costs and errors.

\section{EXPERIMENTAL RESULTS}

The "Polygraph" device consists of two units - analog and digital. The analog part is a set of sensors, which receive the primary signal from the user. Then the signal goes to the digital part, where the signal is digitized and transmitted to the PC. The model of the device is shown in Fig. 1.

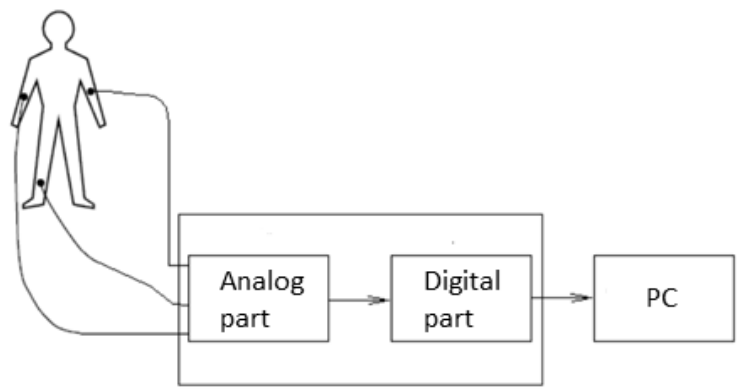

Fig. 1. Device model

Рис. 1. Модель устройства

All sensors are connected to the microcontroller platform through analog inputs, the values received from the sensors are displayed in the terminal window. An oscilloscope is added to the pulse sensor for clarity. The sensor readings are randomly generated, thus simulating real measurement conditions.

The results of the device design are shown in Fig. 2, 3 and 4 on the example of three sensors - a body temperature sensor, a pulse sensor and a flex sensor is connected to the platform. Flex sensor in the future will be attached to the chest and will read the breathing rate of the test subject.

As a temperature sensor, the most common and affordable option was chosen the TMP36 sensor $[6,7]$. This sensor uses solid-state electronics technology to detect temperature. That is, there is no mercury or bimetallic plates. Instead, they have thermistors. In thermistors, as the temperature increases, the voltage in the diode 
rises, technically the voltage difference at the base and emitter in the transistor. Accurate voltage sensing makes it possible to produce an analogue signal proportionally to the temperature [8].

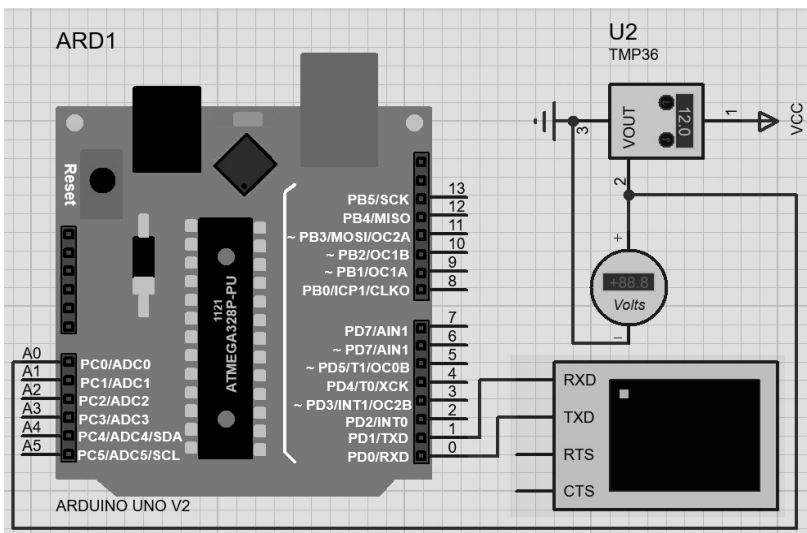

Fig. 2. Temperature sensor model

Рис. 2. Модель датчика температуры

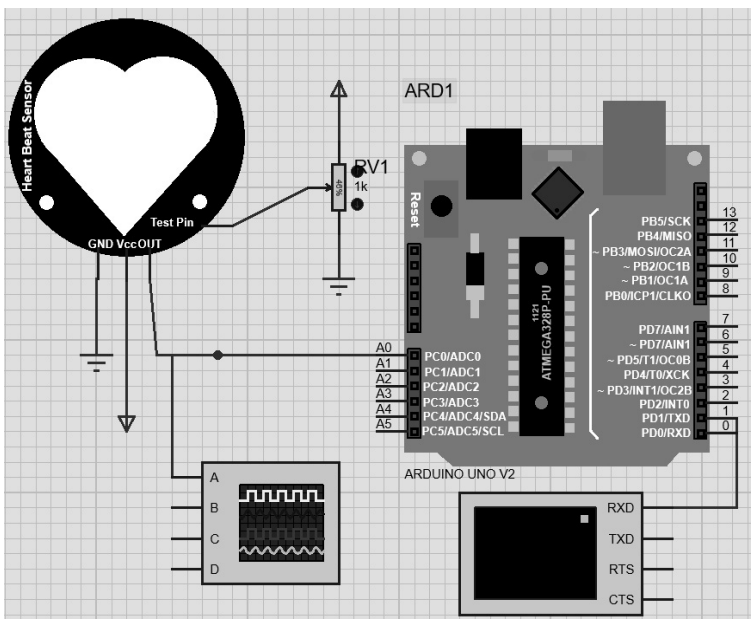

Fig. 3. Pulse sensor model

Рис. 3. Модель датчика пульса 
A photoplethysmograph was chosen for the pulse sensor as the most available and common for this purpose today. This is an analog sensor based on the method of photoplethysmography - the change in the optical density of the blood volume in the area of the body being measured, due to the change in the blood flow through the vessels depending on the phase of the cardiac cycle. The sensor contains a light source and a photodetector, the voltage of which varies depending on the blood volume during cardiac pulsations.

The pulse sensor amplifies the analog signal and normalizes it with respect to the point of average value of the sensor supply voltage. The sensor reacts to intensity changes in light. If the light intensity hitting the sensor stays constant, the signal values will stay near the midpoint of the ADC range. If a greater intensity of study is recorded, the signal curve goes up, if less intensity, the curve goes down, on the contrary.

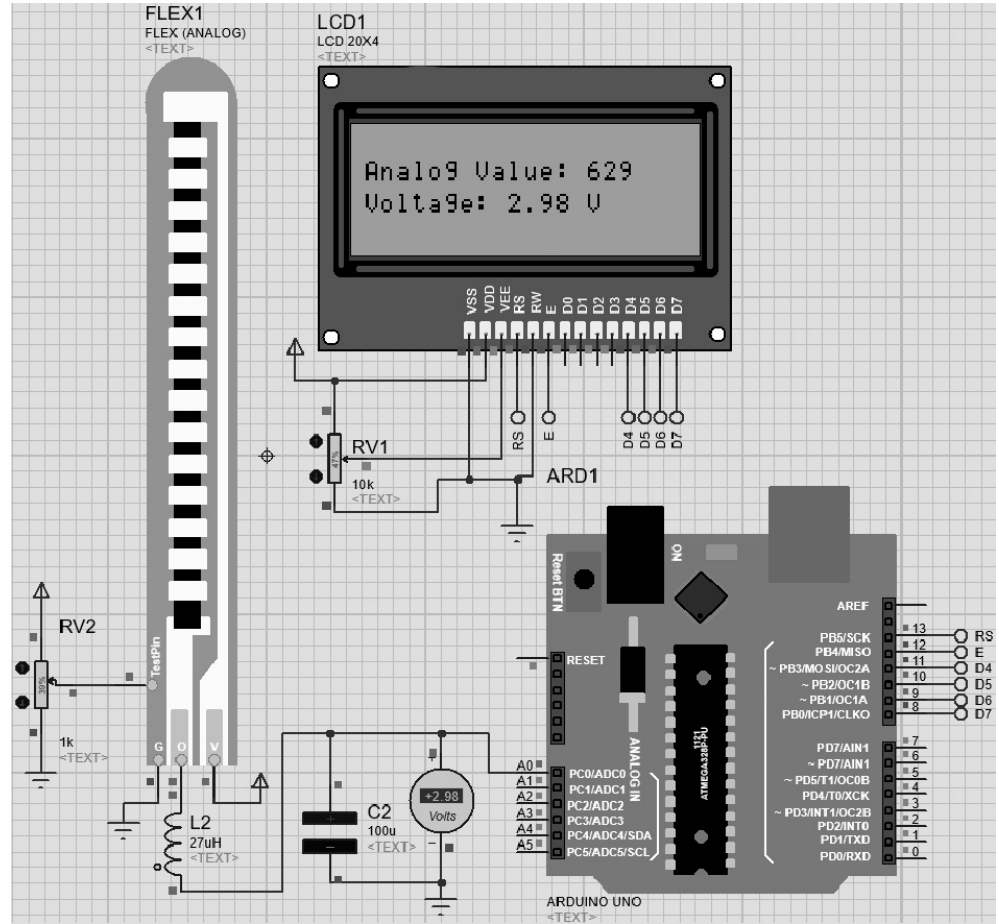

Fig. 4. Flex sensor model

Рuc. 4. Модель гибкого датчика 
Flex sensor is built on resistance carbon elements. The fact that it is a varying print resistor means that it could be made quite long on a slim, elastic base plate. When the base plate is bent, there is some resistance at the output of the sensor, corresponding with the bending radius. In other words, flexible sensors are analog resistors that work as part of a variable analog voltage divider.

The results obtained from the sensors are displayed in the program in the virtual terminal window and are shown in Fig. 5, 6, 7 and 8.

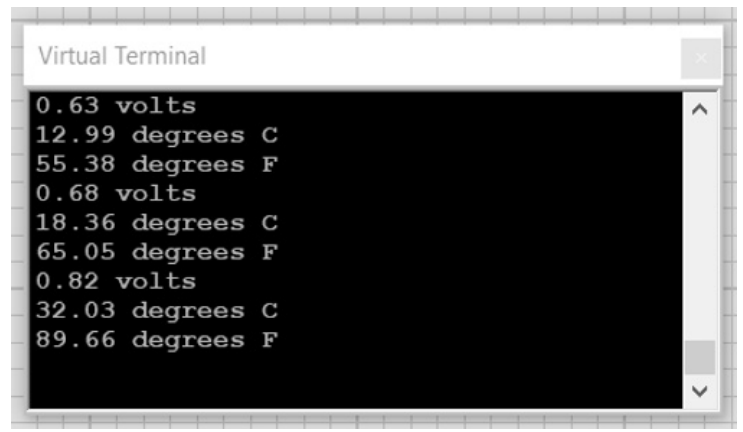

Fig. 5. Temperature sensor results

Puc. 5. Результаты датчика температуры

The temperature sensor is connected to the analog input of the Arduino and, depending on the temperature of the object, outputs different voltage values which are converted into temperature readings [9].

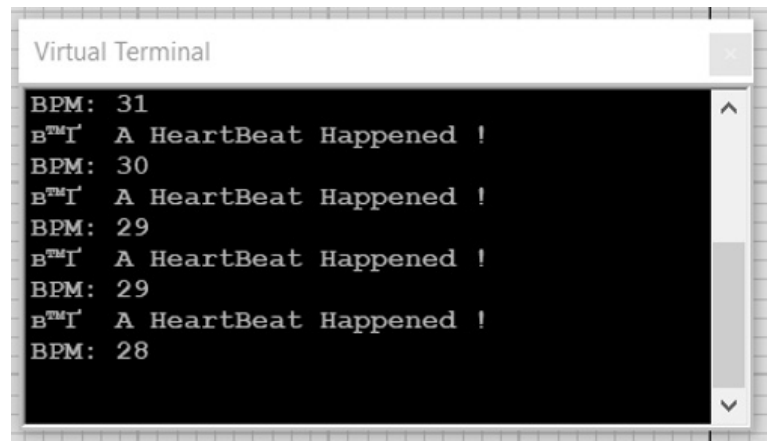

Fig. 6. Pulse sensor results

Рис. 6. Результаты датчика пульса 
The heart rate sensor is also connected to the analog input of the Arduino and records the number of heartbeats [10]. Also an oscilloscope is connected to the pulse sensor circuit, for visual display of time parameters and voltage values of the pulse sensor. These parameters are shown in Fig. 6.

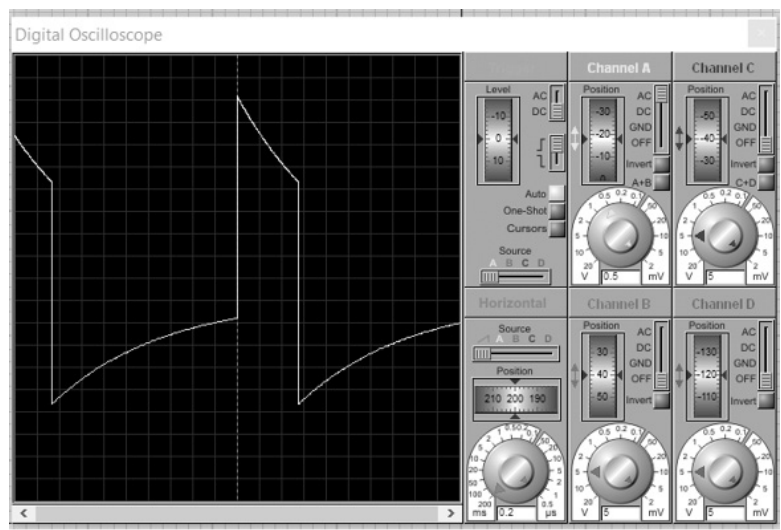

Fig. 7. Time parameters and voltage values of the pulse sensor

Puc. 7. Временные параметры и значения напряжения импульсного датчика

The value of its intensity is proportional to the change in blood filling of the tissue under study during contraction and relaxation of the heart muscle.

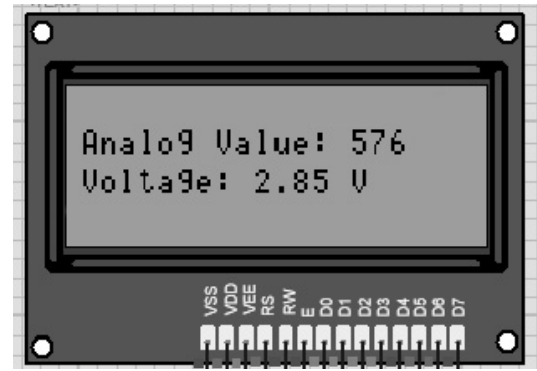

Fig. 8. Flex sensor results

Рuc. 8. Результаты гибкого датчика

The flex sensor is connected to the analog input of the Arduino and, depending on the bending radius of the object, outputs different resistance. 


\section{CONCLUSIONS}

In the course of this research the following tasks were solved: comparative analysis of the most popular freely distributed microcontroller platforms for modeling SHC "Poligraf"; determination of the optimal microcontroller platform and software for visual modeling and training on them; construction of the first training test version of "Poligraf", which displays some parameters measured by real devices. This research shows the promise and relevance of this model for teaching and designing devices such as "Poligraf". Further efforts in work should be directed, in our opinion, on increasing the number of measured parameters, studying and improving metrological characteristics of model samples of the device and increasing reliability of the information provided by the interviewed persons.

\section{REFERENCES}

1. Sal'kova A. Slomannye zhizni: mozhno li verit' "detektoru lzhi"? [Can we trust the lie detector?]. Gazeta.Ru, 2019, 14 April. (In Russian). Available at: https://www.gazeta.ru/science/2019/04/14_a_12299647.shtml (accessed 02.12.2021).

2. Poligrafy na rossiiskom rynke [Polygraphs on the Russian market]. Available at: http://www.bnti.ru/index.asp?tbl=05.13 (accessed 02.12.2021).

3. Monk S. Programming Arduino: getting started with sketches. New York, McGraw-Hill/TAB Electronics, 2011. 162 p.

4. Margolis M. Arduino cookbook. Oreilly, 2014. 800 p.

5. Petracca M., Passaro P., Gioia E. AMBER: advanced mother board for embedded systems pRototyping. EURASIP Journal on Embedded Systems, 2017, vol. 2017, p. 32. DOI: 10.1186/s13639-017-0080-z.

6. Sinha A., Pavithra M., Sutharshan K.R., Subashini M. A MATLAB based on-line polygraph test using galvanic skin resistance and heart rate measurement. Australian Journal of Basic and Applied Sciences, 2013, vol. 7 (11), pp. 153-157.

7. USB Polygraph. Juangg Projects, 2019, June 09. Available at: https:// juangg-projects.blogspot.com/2019/06/usb-polygraph.html (accessed 02.12.2021).

8. Tsapenko M. Izmeritel'nye informatsionnye sistemy: struktury $i$ algoritmy, sistemotekhnicheskoe proektirovanie [Measuring information systems: structures and algorithms, system engineering design]. 2nd ed. Moscow, Energoatomizdat Publ., 1985. 439 p.

9. Datchik temperatury TMP36 i Arduino [Temperature sensor TMP36 and Arduino]. Available at: https://arduino-diy.com/arduino-datchik-temperatury-TMP36 (accessed 02.12.2021).

10. Smirnov V.A. Biofizicheskie osnovy pletizmografii. Registratsiya $i$ analiz fotopletizmogramm [Biophysical basis of plethysmography. Registration and analysis photoplethysmogram]. Blagoveshchensk, 2014. 10 p. 
Viktor A. Mashtakov, master's student of Novosibirsk State Technical University. The main direction of scientific research is the development of automated production systems. E-mail: vitya.mashtakov@gmail.com

Viktor M. Belov, doctor of technical sciences, professor, professor of the Department of Information Protection of Novosibirsk State Technical University. The main direction of scientific research is the application of mathematical methods in various fields of science, technology, society. He has more than 600 scientific publications. E-mail:vmbelov@mail.ru

DOI: $10.17212 / 2782-2230-2021-4-9-19$

\title{
Моделирование программно-аппаратного комплекса «полиграф» на базе свободно распространяемых микроконтроллерных платформ ${ }^{*}$
}

\author{
В.А. Маштаков ${ }^{1}$, В.М. Белов ${ }^{2}$ \\ ${ }^{1}$ 630073, РФ, г. Новосибирск, пр. Карла Маркса, 20, Новосибирский государственный \\ технический университет, магистрант кафедры защиты информаџии. E-таil: \\ vitya.mashtakov@gmail.com \\ ${ }^{2}$ 630073, РФ, г. Новосибирск, пр. Карла Маркса, 20, Новосибирский государственный \\ технический университет, доктор технических наук, профессор кафедры защиты \\ информации.vmbelov@mail.ru
}

Настоящая статья посвящена моделированию программно-аппаратного комплекса (ПАК) «Полиграф» на базе свободно распространяемых микроконтроллерных платформ. Проведен анализ первоисточников и выбрана наиболее перспективная для целей наглядного моделирования и обучения работе на такого рода устройствах платформа микроконтроллера. В рамках задач моделирования на основе ряда критериев определена оптимальная для моделирования устройств автоматизированная система. Используя выбранный инструментарий, авторы смоделировали первую учебную тестовую версию «Полиграфа» с возможностью отображения некоторых параметров, измеряемых реальными ПАК. В статье рассмотрены подключения следующих датчиков ПАК «Полиграфа»: пульса, температуры тела и частоты дыхания; сделан вывод, что данная модель является перспективной и актуальной для целей обучения работе и проектирования устройств типа «Полиграф».

Ключевые слова: компонент, полиграф, микроконтроллерная платформа, датчик, программно-аппаратный комплекс, система автоматизированного моделирования, фотоплетизмограф, модель

\footnotetext{
* Received 10 November 2021.
} 


\section{СПИСОК ЛИТЕРАТУРЫ}

1. Салькова А. Сломанные жизни: можно ли верить «детектору лжи»? // Газета.Ру. - 2019. - 14 апреля. - URL: https://www.gazeta.ru/science/2019/04/ 14_a_12299647.shtml (дата обращения: 02.12.2021).

2. Полиграфы на российском рынке. - URL: http://www.bnti.ru/index.asp? $\mathrm{tbl}=05.13$ (дата обращения: 02.12.2021).

3. Monk S. Programming Arduino: getting started with sketches. - New York: McGraw-Hill/TAB Electronics, 2011. - 162 p.

4. Margolis M. Arduino cookbook. - Oreilly, 2014. - 800 p.

5. Petracca M., Passaro P., Gioia E. AMBER: advanced mother board for embedded systems pRototyping // EURASIP Journal on Embedded Systems. - 2017. Vol. 2017. - P. 32. - DOI: 10.1186/s13639-017-0080-z.

6. A MATLAB based on-line polygraph test using galvanic skin resistance and heart rate measurement / A. Sinha, M. Pavithra, K.R. Sutharshan, M. Subashini // Australian Journal of Basic and Applied Sciences. - 2013. - Vol. 7 (11). P. $153-157$.

7. USB Polygraph // Juangg Projects. - 2019. - June 09. - URL: https://juanggprojects.blogspot.com/2019/06/usb-polygraph.html (accessed: 02.12.2021).

8. Цапенко М. Измерительные информационные системы: структуры и алгоритмы, системотехническое проектирование: учебное пособие. - 2-е изд., перераб. и доп. - М.: Энергоатомиздат, 1985. - 439 с.

9. Датчик температуры TMP36 и Arduino. - URL: https://arduino-diy.com/ arduino-datchik-temperatury-TMP36 (дата обращения: 02.12.2021).

10. Смирнов B.A. Биофизические основы плетизмографии. Регистрация и анализ фотоплетизмограмм: методические указания для самоподготовки студентов / Амурская государственная медицинская академия. - Благовещенск, 2014. $-10 \mathrm{c}$.

Для цитирования:

Mashtakov V.A., Belov V.M. Modeling of a hardware and software complex "Poligraf" based on freely distributable microcontroller platforms // Безопасность цифровых технологий. - 2021. - № 4 (103). - С. 9-19. - DOI: 10.17212/2782-2230-2021-4-9-19.

For citation:

Mashtakov V.A., Belov V.M. Modeling of a hardware and software complex "Poligraf" based on freely distributable microcontroller platforms. Bezopasnost' tsifrovykh tekhnologii $=$ Digital Technology Security, 2021, no. 4 (103), pp. 9-19. DOI: 10.17212/2782-2230-20214-9-19. 